\title{
Introduction: Framing Royal Entries
}

As Louis XI prepared to make his inaugural entry into La Rochelle on 24 May 1472, a civic delegation led by the mayor, Gaubert Gadiot, came to greet him outside the city's walls. During this extramural encounter, Gadiot told Louis that French monarchs were required to swear an oath confirming municipal privileges before being admitted into the city. According to the two notaries who recorded the event, after listening to Gadiot's request, the Valois monarch immediately dismounted his horse, uncovered his head and knelt before the mayor. Louis then confirmed the city's privileges with his hands placed on the copy of the gospels Gadiot held before him. ${ }^{1}$ To modern eyes, Louis XI's gestures - which appear to be unusually submissive - may seem remarkable. They certainly looked that way to Auguste Galland, the seventeenth-century conseiller d'état, who in 1626 pronounced the notarial documents recording Louis's actions to be forgeries. As a royal propagandist, Galland, who had sat on Henry IV's royal council, was not prepared to concede that any king of France would act in such a deferential manner towards his urban subjects even Louis XI, who was known to converse freely with common townspeople. ${ }^{2}$ The manner in which Louis XI confirmed La Rochelle's rights was of crucial importance in the mid-1620s because the rebellious citizens of La Rochelle had published an account of the Valois monarch's behaviour in 1472 during their revolt against Louis XIII (at the heart of which lay the question of local privileges). While Galland's work was written with the specific purpose of refuting the claims of La Rochelle's Huguenot rebels, his views became widely accepted in Bourbon France. For example, the eighteenth-century professor of philosophy and Rochelais historian, Louis Arcère, upheld Galland's royalist reading of the ceremonial entry. However, whereas Galland's work was deliberately prejudiced to the propagation of royal power, as a man of his time Arcère applied scientific rationality to formulate seven supposedly unbiased 'proofs' demonstrating that Louis could not have knelt before the mayor of La Rochelle. ${ }^{3}$

1 Rivaud, Entrées princières, 118.

2 Auguste Galland, Discours sur l'état de la ville de la Rochelle et touchant ses anciens privilèges (Paris, 1626); idem, Discours au roy sur la naissance, ancien estat, propgrez et accroissement de la ville de La Rochelle (Paris, 1629), cxxi-xxix; Léopold Delayant, Histoire des Rochelais, 2 vols (La Rochelle, 1870), ii. 46. For Galland and La Rochelle, see: David Parker, La Rochelle and the French Monarchy: Conflict and Order in Seventeenth-Century France (London, 1980), 154-55.

3 Louis-Étienne Arcére, Histoire de la ville de La Rochelle et du pays d'Aunis, 2 vols (La Rochelle, 1726), ii. 619-21; Rivaud, Entrées princières, 112. 
While the scenes at La Rochelle in 1472 may have been inconceivable for the subjects of the later Bourbon monarchy, Valois kings regularly acted in a humble manner when confirming municipal rights. Indeed, the urban dwellers of later medieval and Renaissance France were accustomed to see their kings kneel as they confirmed urban liberties during a royal entry. Some urban governments were prepared to go to great lengths to ensure that their rulers made a ceremonial entry and confirmed local rights and privileges. Seven years before Louis XI visited La Rochelle, Rouen's leaders sent an armed delegation to compel his brother, Charles, duke of Normandy, to make an entry into the city. Having learned that Charles planned to leave the duchy before making his inaugural entry into the Norman capital, on the evening of 25 November 1465 a group of Rouen's citizens bundled the duke onto his horse and led him through the city's streets. The townspeople's actions ensured that Charles completed his ceremonial entry and was formally installed as duke of Normandy in the cathedral the following day, as part of which he confirmed the privileges of both the city and the duchy. ${ }^{4}$ As illustrated by Louis XI's entry into La Rochelle, and by that of his brother at Rouen, ceremonial entries were fundamental to the granting of urban liberties in Valois France. Because the liberties towns obtained at an entry formed the quintessence of municipal power and autonomy, the entry of a ruler - whether king or duke - was a major event for civic governments across France.

Urban liberties have long held a prominent position in scholarly debates on the emergence of the modern state. For some writers, urban liberties were inimical to the development of modern Western political structures. Writing in reference to France, Karl Marx declared municipal privileges to be part of the 'medieval rubbish' that had inhibited the formation of modern centralized states. ${ }^{5}$ In contrast, Max Weber considered the development of medieval urban liberties to form a crucial moment in the formation of European liberal societies. ${ }^{6}$ Likewise, many prominent nineteenth-century historians, such as François Guizot and Augustin Thierry, located the origins of modern

4 Basin, Histoire de Louis XI, i. 235-41; Philippe de Commynes, Mémoires, J. Blanchard, ed., 2 vols. (Paris, 2007), i. 80-81; Jacques Duclercq, Mémoires, J. A. Buchon, ed. (Paris, 1827), 85-87; Chronique scandaleuse, i. 141-42.

5 Jon Elster, ed., Karl Marx: A Reader (Cambridge, 1986), 285.

6 Max Weber, The City (New York, 1921). See also: Wolfgang J. Mommsen, 'Max Weber's "Grand Sociology": The Origins and Composition of Wirtschaft und Gesellschaft. Soziologie', in Charles Camic, Philip S. Gorski and David M. Trubek, eds., Max Weber's 'Economy and Society': A Critical Companion (Stanford, 2005), 91-92; David Stasavage, 'Was Weber Right? The Role of Urban Autonomy in Europe's Rise', American Political Science Review 108 (2014), 337-54. 
democracy in the political and economic rights held by pre-modern townspeople - a view that was echoed in the 1960s by Barrington Moore, who memorably stated: 'no bourgeoisie, no democracy'. ${ }^{7}$ More recently, historians such as Wim Blockmans, Maarten Prak, Mark Dincecco and Stephan Epstein have debated the role that urban privileges played in the development of preindustrial European states. ${ }^{8}$

Yet while historians, political scientists and sociologists have given urban liberties a prominent position in their examinations of the emergence of the modern state, French historians have paid little attention to the fundamental place that negotiations for urban rights occupied in a ceremonial entry. This is a considerable oversight, as by the early fourteenth century urban liberties were typically confirmed during a ceremonial entry. As well as staging entries in order to obtain the re-confirmation of their existing rights, urban administrations used these events to petition the king for new liberties; indeed, a ceremonial entry provided the rulers of French towns with arguably the best opportunity to win lucrative new rights from the Crown. The following chapters systematically analyse the strategies urban elites devised to obtain both the ratification of their charters and the augmentation of their liberties. In order to understand the wider importance of these grants for urban governments, this book grounds the petitions for liberties within the sweeping political, social, economic and religious changes that occurred in Valois France.

7 François Guizot, Histoire de la civilisation en Europe (Paris, 1870), 189-220; Augustin Thierry, Essai sur l'histoire de la formation et des progrès du Tiers État; suivi de deux fragments du recueil des monumens inédits de cette histoire (Paris, 1883); Barrington Moore, Social Origins of Dictatorship and Democracy: Lord and Peasant in the Making of the Modern World (Boston, 1966), 418. See also: Dietrich Gerhard, 'Guizot, Augustin Thierry und die Rolle des Tiers État in der französischen Geschichte', Historische Zeitschrift 190 (1960), 290-310; Neithard Bulst, 'Stadt und Bürgertum und die Anfänge des modernen Staats', in Neithard Bulst and JeanPhilippe Genet, eds., La ville, la bourgeoisie et la genèse de l'État moderne (XII ${ }^{e}-X V I I I^{e}$ siècles) (Paris, 1988), 13.

8 Wim Blockmans, 'Voracious States and Obstructing Cities: An Aspect of State Formation in Preindustrial Europe', Theory and Society 5 (1989), 733-55 (see also the revised version of this article printed in Wim Blockmans and Charles Tilly, eds., Cities and the Rise of States in Europe, AD 1000 to 1800 [Boulder, 1994], 218-50); Wim Blockmans and Marjolein 't Hart, 'Power', in Peter Clark, ed., The Oxford Handbook of Cities in World History (Oxford, 2013), 421-37; Ann Katherine Issacs and Maarten Prak, 'Cities, Bourgeoisies, and States', in Wolfgang Reinhard, ed., Power Elites and State Building (Oxford, 1996), 207-34; Mark Dincecco, Political Transformations and Public Finances: Europe, 1650-1913 (Cambridge, 2011); Stephan Epstein, Freedom and Growth: The Rise of State and Markets in Europe 1300-1750 (London, 2000); Stephan Epstein and Maarten Prak, Guilds, Innovation and the European Economy, 1400-1800 (Cambridge, 2008). 
An entry provided urban governments with an opportunity to offer the ruler (or his representatives) petitions regarding their rights, liberties and customs. While this was the most important aspect of the ceremony for municipal elites, historians have not made it their principal object of study. The issue of urban rights and liberties is frequently omitted - or else touched upon only briefly - in the bulk of the works examining the development of the French entry ceremony. In part, this disregard for urban liberties is a legacy of the work of the royal historiographers of the early Bourbon monarchs, whose published collections of documents relating to the ceremonies of the French monarchy set the initial parameters for the study and interpretation of entries. For example, André Duchesne's Antiquités et Recherches de la grandeur et Majesté des Roys des France (1609) presents the royal entry as a ceremony that was principally about the submission of townspeople before the majesty of the monarch. He provides no sense of the king's deferential behaviour towards urban delegations, or his obligation to confirm municipal liberties. Drawing on a range of contemporary documents from the fourteenth century onwards, Duchesne omits the aspects of the ceremony that were concerned with urban rights. By redacting or altering the sources, Duchesne was able to accentuate those elements of an entry which glorified the power of the French monarchy. ${ }^{9}$

While the publication of Duchesne's collection marked a significant moment in the interpretation of these ceremonies, the most important of the various works on entries prepared by royal historiographers in the seventeenth century is Théodore Godefroy's Le Cérémonial de France (1619). This significant work was followed by an enlarged version, printed by his son, Denis (who, like his father, was a royal historiographer), in 1649 under the title Le Cérémonial françois. ${ }^{10}$ In these two collections (but especially in the 1649 edition), the Godefroys created long roots for the absolutism of the seventeenth-century French monarchy by devising an overarching coherence to almost a millennia's worth of ceremonies, from the entry of the Frankish King Guntram into Orléans in 588 to Louis XIV's inaugural entry into Paris in 1643. Within the pages of Le Cérémonial françois, the Godefroys present the reader with a vast (Paris, 1609), 477-96. This book drew on Jean du Tillet's Recueil des roys de France, which was commissioned by Henry II in 1548 but not published until 1578 (see BNF français 2848): Michèle Fogel, Les cérémonies de l'information dans la France du XVIe au milieu $d u$ XVIII e siècle (Paris, 1989), 161, 193; Lawrence Bryant, 'Making History: Ceremonial Texts, Royal Space, and Political Theory in the Sixteenth Century', in Michael Wolfe, ed., Changing Identities in Early Modern France (Durham, NC, 1997), 47, 162. 
panoply of interlinked ceremonies, all of which championed the majesty of the French monarchy. ${ }^{11}$

Godefroy began Le Cérémonial françois with a dedication to Louis XIV ('the first and most royal in Europe, and by consequence in all the world'), in which he asked young Bourbon monarch to receive the book as a gift. Godefroy went on to state that all the ceremonies contained in its pages were the just and reasonable obligations which the French must [make] to the Majesty of their sovereigns; who, as God orders them, are considered and beheld in this world as the principal images and likenesses of divine Majesty'.12 Godefroy's fabrication of a long-standing absolutist character for these ceremonies was influential and it set the tone for the ways in which royal entries were presented in Bourbon France. For example, the seventeenth-century antiquarian and heraldist Claude-François Menestrier (1631-1705) avowed that entries were 'demonstrations of public joy mingled with marks of submission and respect' which reflected the unbridled power of the French monarchy. ${ }^{13}$ In the works of Godefroy and Menestrier (like those of Arcère and Galland), there is little sense of the reciprocal obligations that lay at the heart of an entry ceremony in Valois France. For the advocates of Bourbon power, entries were unquestionably a manifestation of royal majesty.

The presence of a number of mutually reinforcing tendencies in the modern historiography of entries has sustained key aspects of the approach taken by these seventeenth- and eighteenth-century writers. In particular, historians continue to pay undue attention to the pageantry deployed during these events. In her Les entrées solennelles et triomphales à la Renaissance (1484-1511) - which can probably be considered the first modern study of the French royal entry ceremony - Josèphe Chartrou analyses the content of the decorations and pageantry staged during royal entries in early Renaissance France. ${ }^{14}$ Although Chartrou's book marked an important moment in the evolution of the study of French royal entries, its focus on the pageantry largely upheld the royalist views of Godefroy and Menestrier. More importantly, while Chartrou's work is now almost ninety years old, its influence on the historiography of the French

11 Godefroy, Cérémonial français, ii. 634, 1003-4.

12 Godefroy, Cérémonial français, i. n.p.

13 C.-F. Menestrier, Décorations faites dans la ville de Grenoble, capitale de la province de Dauphiné, pour la réception de monseigneur le duc de Bourgogne, et de monseigneur le duc de Berry avec des réflexions et des remarques sur la pratique \& les usages des décorations (Grenoble, 1701), 71.

14 Josèphe Chartrou, Les entrées solennelles et triomphales à la Renaissance (1484-1551) (Paris, 1928). 
royal entry has been enduring, largely because she devised the paradigm of how to study the ceremony. ${ }^{15}$ Although an entry framed a range of practices, Chartrou privileged the decorations and pageantry over all the other elements. While many subsequent studies of entries have provided more refined analyses of the symbolism, Chartrou's focus on the pageantry remains the principal way in which historians tackle these events. As a consequence, they have given limited treatment to the confirmation of urban privileges. The sole mention Chartrou makes regarding privileges is a half a sentence where she observes that French kings customarily took an oath to confirm the rights of the French Church at their inaugural entries into Paris. ${ }^{16}$ While many subsequent studies of French royal entries recognise that the confirmation of urban rights was central to the events, they do not treat this issue in any depth. ${ }^{17}$ Lawrence Bryant is one of the few historians to explore the wider role of rights within an entry, though his focus is not specific to the confirmation of urban liberties; rather, he looks more broadly at the confirmation of offices a French king was expected to make upon coming to throne. Moreover, by focusing on Paris (which as the administrative centre of the kingdom was unique in the range and number of offices the monarch confirmed) Bryant's gaze extends far beyond the privileges of the municipal council. Finally, as Bryant notes, the distinctive nature of the

15 In the decades following the publication of Les entrées solennelles et triomphales, Chartrou's approach was adopted by a number of historians, such as Antoinette Huon, V. L. Saulnier, Frances A. Yates and Georges Kernodle: George R. Kernodle, From Art to Theatre: Form and Convention in the Renaissance (Chicago, 1943); idem, 'Renaissance Artists in the Service of the People. Political Tableaux and Street Theater in France, Flanders and England', Art Bulletin 25 (1943), 59-64; Antoinette Huon, 'Le thème du prince dans les entrées parisiennes au XVI e siècle'; V. L. Saulnier, 'L'entrée de Henri II à Paris et la révolution poétique de 1550'; Frances A. Yates, 'Poètes et artistes dans les entrées de Charles IX et de sa reine à Paris en 1571', in Jean Jacquot, ed., Les fêtes de la Renaissance (Paris, 1956), 21-30, 31-59, 61-84.

16 Chartrou, Entrées solennelles, 16.

17 See: Jean Boutier, Alain Dewerpe and Daniel Nordman, Un tour de France royal: le voyage de Charles IX (1564-1566) (Paris, 1984), 295, 296; Annette S. Finley-Croswhite, Henry IV and the Towns: The Pursuit of Legitimacy in French Urban Society, 1589-1610 (Cambridge, 1999), 47-62; Ralph Giesey, 'Models of Rulership in French Royal Ceremonial', in Sean Wilentz, ed., Rites of Power: Symbolism, Ritual and Politics Since the Middle Ages (Philadelphia, 1985), 52; Gordon Kipling, Enter the King: Theater, Liturgy and Ritual in the Medieval Civic Triumph (Oxford, 1998), 39-40; Roy Strong, Art and Power: Renaissance Festivals, 1450-1650 (Woodbridge, 1984), 7; Michael Wintroub, A Savage Mirror: Power, Identity, and Knowledge in Early Modern France (Stanford, 2006), 3. 
confirmation of liberties during Parisian entries was atypical of other French towns and cities. ${ }^{18}$

While some of the most sophisticated modern studies of French royal entries have moved beyond Chartrou's royal-centred focus by developing Bernard Guenée's idea that royal entries were 'an occasion for dialogue' between the king and his urban subjects, Guenée's point has been largely been conceptualised in terms of the messages urban governments put forward in the festivities. In A Savage Mirror Michael Wintroub provides a focused study of one entry (Henry II's entry into Rouen in 1550), which he grounds in the cultural world of French urban elites. He investigates the social and political messages the Rouennais conveyed in the drama and makes wider points about how royal authority was represented in sixteenth-century France. While Wintroub notes that in return for receiving a magnificent ceremonial reception 'entering kings were expected to reaffirm the customary rights and privileges of a city's citizenry and clergy', he spends the book examining the symbolism of the entry's performances and decorations. ${ }^{19}$ In short, while the perspective of the recent historiography of royal entries may have shifted from the king to the urban elite, the focus of these studies remains firmly on the symbolism of the decorations and dramatic performances. ${ }^{20}$

By placing an entry's thematic programme at the centre of their work, historians have defined these ceremonies by the presence of pageantry. Yet by using drama as the benchmark with which to judge an entry, they have been overly restrictive in the scope of their work. Before the late fifteenth century, many towns did not include theatre or pageantry in their entries. Even by the sixteenth century (when the French royal entry ceremony reached its height in terms of display) not all ceremonial receptions contained theatrical representations. As such, we cannot define an entry by the presence of pageantry alone. Furthermore, historians' focus on the development of the dramatic performances favours the major cities of the kingdom, which possessed the financial and material reserves necessary to produce magnificent entries.

18 Bryant, King and the City, 114. For the confirmaiton of Paris's liberties see also: Lawrence Bryant, 'The Medieval Entry Ceremony at Paris', in Janos Bak, ed., Coronations: Medieval and Early Modern Ritual (Berkeley, 1990), 94, 104, 111-12.

19 Wintroub, A Savage Mirror, 3.

20 For recent examinations of the performances and iconography of ceremonial entries, see: J. R. Mulryne, Maria Ines Aliverti and Anna-Maria Testaverde, eds., Ceremonial Entries in Early Modern Europe: The Iconography of Power (Farnham, 2015); Margaret Shewring, ed., Waterborne Pageants and Festivities in the Renaissance: Essays in Honour of J. R. Mulryne (Farnham, 2013). 
As a consequence of this approach, historians have paid little attention to the entries staged by smaller urban communities. Yet, a ceremonial entry served the same purpose for a small town as it did for a large city. That is to say, it provided the governments of towns of all sizes with an opportunity to petition the ruler for the ratification or expansion of their liberties. By excluding entries that were devoid of pageantry from their studies, historians have not recognized the importance these ceremonies had for smaller urban communities. Instead of using pageantry as an entry's defining characteristic, we should look for the presence of an official welcome outside the town walls. ${ }^{21}$ Urban administrations in pre-modern France considered the extramural greeting (along with the gift presentation) to be more important than the content of the plays and decorations. Consequently, civic rulers spent the bulk of their time discussing the extramural greeting and gift giving, rather than the thematic programme. Given the significance of the greeting and gift exchange for urban governments, the first half of this book examines these key aspects of an entry in depth.

The tendency to privilege the intra-mural theatrical elements of an entry has encouraged many historians to view a royal entry fundamentally as a manifestation of royal power. In these works, royal entries are presented as a form of state propaganda which the monarchy used to impose its control over urban communities, and there is little sense of the important role these occasions played in civic life. ${ }^{22}$ From the king's perspective, the drama and decorations - which were devised in his honour - were the most important parts of the ceremony. Yet by concentrating on the drama and spectacle of an entry, some historians have viewed the production of pageantry to glorify the king as the principal purpose of an entry. Gordon Kipling avers that an entry's 'primary function' was 'as a serious late medieval art form - in Huizinga's terms, one of the "supreme expressions" of late medieval culture, one of its most serious modes of collective enjoyment, and a deeply felt assertion of communal solidarity.'23 As well as questioning the degree to which entries were a

21 On this point, see: Teofilo F. Ruiz, A King Travels: Festive Traditions in Late Medieval and Early Modern Spain (Princeton, 2012), 116.

22 Sydney Anglo, Spectacle, Pageantry, and Early Tudor Policy (Oxford, 1969); R. J. Knecht, 'Court Festivals as Political Spectacle: The Example of Sixteenth-Century France', in J. R. Mulryne, Helen Watanabe-O'Kelly and Margaret Shewring, eds., Europa Triumphans: Court and Civic Festivals in Early Modern Europe, 2 vols (Aldershot, 2004), i. 19, 21; idem, The French Renaissance Court, 1483-1589 (London and New Haven, 2008), 99-106; Kipling, Enter the King; Pascal Lardellier, Les miroirs du paon: rites et rhétoriques politiques dans la France de l'Ancien Régime (Paris, 2003); Strong, Art and Power. 
manifestation of 'communal solidarity', this book argues that municipal elites did not devise these events principally for artistic purposes. The inclusion of artistic elements within an entry was a means to an end rather than an end in itself. Urban elites deployed these cultural products to encourage the king or his representatives to ratify and extend the rights and liberties that maintained their control of local political and economic structures. This is not to downplay the many merits of Kipling's work, as these ceremonies were undoubtedly vehicles for the deployment of some of the greatest artistic manifestations of the age; however, in this book I aim to show that we should not simply see entries as artistic manifestations that were designed to glorify the power of the king. While the decorations and dramatic performances framed a town's efforts to obtain new liberties, they were not the most important part of the ceremony for urban elites.

By privileging the thematic programme, historians have only focused on one of the many methods of communication townspeople used to speak with the king during an entry. Furthermore, it is clear that the complex symbolism of the decorations and performances was not an effective way to communicate with the king, particularly during the sixteenth century when the messages and ideas conveyed in the allegorical scheme became especially elaborate. From the reign of Charles VIII, entries became replete with obscure classical allusions and Greek and Latin text. Michael Wintroub has demonstrated how a French 'civic-cultural elite' used the thematic programme of an entry to highlight their learning, command of languages and civility. ${ }^{24}$ Yet these messages and allusions were so complex that they could only be understood be understood by a privileged few. When we take the example of Henry II's entry into Rouen in $155^{\circ}$ (for which there are several surviving eyewitness accounts), we can clearly see the difficulties that even the highly educated had in understanding the complex iconographical messages put forward in these ceremonies. First, the imperial ambassador, Simon Renard, who watched the event with the French king, misunderstood most of what he saw. Indeed, he informed his master, Emperor Charles v, that he found the entry's symbolism too complex. ${ }^{25}$ Second, the Oxford-educated English ambassador, Sir John Mason (later appointed chancellor of the University of Oxford), mistakenly believed that a mock naval battle staged during the course of the entry was as a performance depicting the defeat of the English (in fact, it was meant

\footnotetext{
24 Wintroub, A Savage Mirror, 185-90.

25 Royall Tyler, ed., Calendar of Letters, Despatches, and State Papers, Relating to the Negotiations Between England and Spain, Vol. X: Edward VI, 1550-1552 (London, 1914), 183.
} 
to represent an encounter between French and Portuguese ships). ${ }^{26}$ During politically sensitive times, difficulties in deciphering an entry's symbolism could do more than deflate an ambassador's ego. Henry II's entry into Rouen came soon after England lost Boulogne to France and Mason's misunderstanding of the drama had the potential to provoke a serious diplomatic incident. As the thematic programme of the Rouen entry threatened to spark off unwanted consequences, Henry II ordered the échevins to remove the offending pageant from the reception given to his wife, Catherine de Medici, when she entered the city after him. ${ }^{27}$

The inability of educated men such as Simon Renard and Sir John Mason to understand the messages conveyed in an entry's symbolism highlights the gulf which existed between the intentions of those who produced the drama and the reality of how it was perceived. More importantly, we can question the degree to which the monarch was able to comprehend what he saw; indeed, it is probable that many kings understood little of the thematic content. Clearly, monarchs who came to the throne as children, such as Charles viII, lacked the scholarly capacity to interpret the difficult symbolism of their entries. Additionally, it is doubtful that many adult monarchs understood all of the theatrical representations. Some towns were aware of this problem and took steps to explain the meaning of the performances to the king (and those who travelled with him) by including written explanations of the scenes beside the stages. ${ }^{28}$ Yet even the ability to grasp the content of these placards necessitated a high level of education and a good command of languages. For Louis XII's entry into Rouen in 1508 the placards were in both Latin and French. As the French text was not a translation of the Latin, the viewer would need to be able to read both parts to fully appreciate the scene. ${ }^{29}$ France's intellectual elite devised these texts and the ability to understand the messages conveyed in the verses (which was frequently not a straight explanation of the

26 P. F. Tytler, ed., England Under the Reigns of Edward VI and Mary, 2 vols (London, 1839), i. 325. Spectators struggled to interpret the complex symbolism at entries across Europe. The English herald, Thomas Whiting, who witnessed Margaret of York's entry into Bruges in 1468 , wrote that 'the pageauntes were soo obscure that y fere me to wryte or speke of them because all was coutenaunce and noo words'. Cited in: Gordon Kipling, 'Brussels, Joanna of Castile, and the Art of Theatrical Illustration (1496)', Leeds Studies in English 32 (2001), 238.

27 CSP Spain, $1550-1552,182-83$.

28 For the use of placards for explication, see: Ам Compiègne вв 18, fol. 118v (Eleanor of Austria, 1531); Albert Babeau, Les rois de France à Troyes au seizième siècle (Troyes, 1880), 16 (Louis XII, 1510); Ledieu, 'Charles VIII à Abbeville', 60.

29 P. Le Verdier, ed., L'entrée de Roi Louis XII et de la Reine à Rouen (1508) (Rouen, 1900), 10-12. 
scene) necessitated a high level of education. In preparation for Charles IX's entry into Troyes in 1564, the town council hired the poet Jean Passerat, professor at the Collège de Beauvais at Paris, to devise verses in French and Latin that were placed beside the performance stages. ${ }^{30}$ When we remember that Charles was only fourteen years old at the time of his entry into Troyes, we can probably question his ability to understand the messages conveyed in the placards, not to mention the complex symbolism of the decorations and pageantry. Of course, it is possible that the difficult material contained in both the performances and the written explanations was not principally intended for the king. It may be that a 'civic-cultural elite' (to borrow Michael Wintroub's term) devised these spectacles for their own appreciation, rather than formulating symbolism that the king could easily understand (which would probably have been less intellectually satisfying). Regardless of the intended audience, a consideration of the complexity of the thematic programmes has serious implications for how we study ceremonial entries. We must reconsider the supposed efficacy of pageantry as a means of communication between town and Crown. In contrast to the difficult messages conveyed in the decorations and performances, this book examines the direct communication that took place during the extramural greeting and the gift exchange between civic leaders and the king and his minsters over the issue of liberties. Given that the legal and economic existence of a town was at stake in the discussions about liberties, it was imperative that urban administrations ensured that there was no ambiguity or misunderstanding in these parts of the ceremony.

In sum, rather than provide another examination of the drama and the allegorical allusions of a ceremonial entry, this book will uncover and account for the role that entries played in winning liberties and obtaining influence at court. While municipal councils used the drama of the intramural procession to communicate their ideas about good kingship to the monarch, the extramural greeting and gift presentation were the most important elements of the ceremony for urban governments. Although entries were ephemeral events, the political and economic rights towns gained at these occasions could last for generations. This book examines the dialogue that took place between the urban elite and the Crown regarding the political, economic and judicial liberties that underpinned urban life in pre-modern France. As we shall see, negotiation between Crown and town pervaded all levels of an entry ceremony. By focusing on the granting of urban liberties, this book reveals an important way in which power worked in pre-modern France. 


\section{Sources and Perspectives}

The widespread use of chronicles and festival books has encouraged historians to focus on the theatre of the entry. ${ }^{31}$ While these texts provide an extended exegesis of the symbolism of the performances and the decorations, they tell us little about how urban elites used an entry ceremony to gain direct contact with the king and petition him for rights and liberties. The principal studies of medieval French entries are largely based on chroniclers' descriptions of these ceremonies. These texts focus on the elements of an entry that glorified the monarch, especially the theatrical performances, which first appeared in France during the $1380{ }^{32}$ While chroniclers played a key role in promoting a royalist reading of a ceremonial entry, the adoption of the printing press in France revolutionised the Crown's ability to use narrative accounts of entries to promote its power. Simple livrets detailing entries were published from the 1480 s, which were followed by the production of lavishly illustrated festival books in the early sixteenth century. These literary texts revolutionised the interpretation of entries by providing highly detailed accounts of the symbolism of the pageants and the decorations. Festival books became a crucial

31 For festival books, see: William Kemp, 'Transformations in the Printing of Royal Entries during the Reign of François Ier: The Role of Geofroy Tory', in Nicholas Russell and Hélène Visentin, eds., French Ceremonial Entries in the Sixteenth Century: Event, Image, Text (Toronto, 2007), 111-32; Margaret M. McGowan, 'The French Royal Entry in the Renaissance: The Status of the Printed Text', in Russell and Visentin, French Ceremonial Entries, 29-54; Hélène Visentin, 'The Material Form and the Function of Printed Accounts of Henri II's Triumphal Entries (1547-51)', in Marie-Claude Canova-Green, Jean Andrews and Marie-France Wagner, eds., Writing Royal Entries in Early Modern Europe (Turnhout, 2013), 1-30; Helen Watanabe-O'Kelly, 'The Early Modern Festival Book: Function and Form', in J. L. Mulryne, Helen Watanabe-O'Kelly and Margaret Shewring, eds., Europa Triumphans: Court and Civic Festivals in Early Modern Europe, 2 vols (Farnham, 2004), 3-18; idem, 'Festival Books in Europe from Renaissance to Rococo', The Seventeenth Century 3 (1988), 181-201.

See, especially: Kipling, Enter the King. Prior to this, accounts of the entries of the early Valois monarchs are frequently sparse, reflecting the basic processional structure and lack of pageantry. For Philip vi's post-coronation entry into Paris on 18 June 1328, the Grandes Chroniques de France (which acted as the Crown's official record for late-medieval entries into Paris) simply remarks that the king 'was honourably received'. Likewise, when Charles v entered Rouen in 1364, the Chronique des Quatre Premiers Valois records only that he 'was very joyously and very solemnly received': Jules M. E. Viard, ed., Les Grandes Chroniques de France, 10 vols (Paris, 1920-53), ix. 79; Guenée and Lehoux, Entrées royales françaises, 48; Siméon Luce, ed., Chronique des quatre premiers Valois (1327-1393) (Paris, 1862), 149 . 
counterpart to the ceremony precisely because the thematic programmes of royal entries had grown so complex by the sixteenth century that they could not easily be understood, even by those people who watched the event.

Although historians have used festival books to try and reconstruct the practices and meanings of royal entries, there are a number of problems with these sources. While festival books purport to provide a faithful description of how the entry passed off on the day, the authors of these sources regularly distorted or manipulated their material, such as Maurice Scève who prepared the festival book for Henry II's entry into Lyon in 1548. As Scevè had designed the thematic programme for the entry, he was in an ideal position to give an accurate record of the ceremony. Yet in the festival book he prepared to commemorate the event, Scève deliberately changed the text of some of the inscriptions displayed on the decorations, as well as redacting other material. ${ }^{33}$ Festival books were typically produced with the intent of glorifying the king and authors changed or omitted information to suit this end and endear themselves to the monarch (Scève's preparation of Henry II's entry into Lyon and its festival book contributed to his ascendancy in the cultural world of sixteenthcentury France ${ }^{34}$ ). Festival books were part of a genre that had its own rules and traditions - and these conventions led authors to put down in writing only the aspects of the entry that brought glory on the king and those who staged the event. ${ }^{35}$

While festival books are closely associated with the propagation of royal power, civic governments commissioned many of these texts. In addition to hiring writers to draw up festival books, members of town councils prepared their own works. For example, the Parisian échevin Simon Bouquet penned the published account of Charles IX's entry into the city. ${ }^{36}$ As well as sitting on the town council, Bouquet was a poet and worked with Pierre de Ronsard (the leading member of the Pléiade) on the programme of festivities for

33 Knecht, French Renaissance Court, 99-100.

34 Ruth Mulhauser, Maurice Scève (Boston, 1977), 34-35.

35 Helen Watanabe-O'Kelly, 'Early Modern European Festivals - Politics and Performance, Event and Record', in J. R. Mulryne and Elizabeth Goldring, eds., Court Festivals of the European Renaissance: Art, Politics and Performance (Aldershot, 2002), 22-23.

36 Frances A. Yates, ed., La ioyeuse Entrée de Charles IX roy de France en Paris, 1572 (Amsterdam, 1976); Victor E. Graham and W. McAllister Johnson, eds., The Paris Entries of Charles IX and Elisabeth of Austria, 1571: with an analysis of Simon Bouquet's 'Bref et sommaire récueil' (Toronto, 1974). See also: Charles Brucker, 'Pour un statut d'auteur d'emblèmes au XVIe siècle: Simon Bouquet et la tradition alciatique', in Lise Sabourin, ed., Le Statut littéraire de l'écrivan (Geneva, 2007), 215-46. 
Charles's entry. ${ }^{37}$ One the one hand, Bouquet's status as a poet and his involvement with the production of the entry meant that he was well placed to explain the complex symbolism to the reader. However, there are a number of reasons why the festival books produced by civic governments are problematic, especially when they are used to try and reconstruct an entry ceremony. First, urban elites used festival books as a means to assert their intellectual prowess. As Michael Wintroub remarks, 'printed accounts of entries were less about the normalization and extension of the entry rituals themselves, than about the articulation and advancement of the kinds of people who could write - or at least, understand - their arcane and technical vocabulary. ${ }^{\prime 3}$ As such, the civic authors of festival books presented a particular version of an entry in order to sustain their elevated social position. Second, urban governments shaped the content of festival books in order to promote the pre-eminence of their city. Specifically, urban elites highlighted their wealth and power by devising festival books that emphasised the scale (and thus the high cost) of an entry's decorations and pageantry. The focus on the performances also drew attention to the city council's loyalty to the ruler, for whom they had prepared a magnificent entry. ${ }^{39}$ In addition, urban elites devised festival books to promote their towns on both the national and the international stages. ${ }^{40}$ Finally, whether festival books were produced by royal or urban sources, these texts were designed to set down the official interpretation of the entry. ${ }^{41}$ Hence, authors of festival books were highly selective about what practices they included in their accounts. As Helen Wantanabe-O'Kelly has observed, 'early modern courtly

37 Frances A. Yates, Astraea: The Imperial Theme in the Sixteenth Century (London, 1975), 141-44, 146.

38 Wintroub, A Savage Mirror, 188.

39 On this point, see also: Werner Waterschoot, 'Antwerp: books, publishing and cultural production before 1585', in Patrick O'Brien, Derek Keene, Marjolein 't Hart and Herman Van Der Wee, eds., Urban Achievement in Early Modern Europe: Golden Ages in Antwerp, Amsterdam and London (Cambridge, 2001), 247.

40 Wim Blockmans \& Esther Donckers, 'Self-Representation of Court and City in Flanders and Brabant in the Fifteenth and Early Sixteenth Centuries', in Wim Blockmans \& Antheun Janse, eds., Showing Status: Representation of Social Positions in the Late Middle Ages (Turnhout, 1999), 108; Gordon Kipling, 'The King's Advent Transformed: The Consecration of the City in the Sixteenth-Century Civic Triumph', in Nicholas Howe, ed., Ceremonial Culture in Pre-Modern Europe (Notre Dame, 2007), 122-23. See also John Landwehr, Splendid Ceremonies: State Entries and Royal Funerals in the Low Countries, 1515-1791 (Niueuwkoop, 1971), 73-75.

41 Peter Arnade, Realms of Ritual: Burgundian Ceremony and Civic Life in Late Medieval Ghent (Ithaca, 1996), 194. 
historiography... is meant to be biased, and so are festival books. ${ }^{42}$ While entries were transitory events, festival books were intended to fix the lasting interpretation of the event. Quite simply, royal entries were too politically important for the published accounts of these ceremonies not to be altered to support the aims of the political authorities that commissioned them.

Historians have a long tradition of adopting methodologies from other fields of study (especially the social sciences) to assist them with the interpretation of human behaviour. Keith Thomas, Lynn Hunt and Natalie Zemon Davis have all encouraged historians to borrow analytical models from other disciplines and apply them to their particular object of study, whether that be Anglo-Saxon kingship rights, medieval sainted dogs or political discourse in Revolutionary France. ${ }^{43}$ These interpretative models promise to unlock the meaning of ceremonial practices. At its best, the adoption of social scientific methodologies has reminded historians of the need to situate a ceremony firmly within the wider political, social, religious and cultural contexts of the society that produced it. However, the use of anthropological and sociological methodologies can produce a distorted understanding of the practices embedded within an entry when it is applied uncritically to a limited or highly biased body of source material, such as festival books. At the crux of Philippe Buc's assault on historians' use of social scientific methodologies is his assertion that we can only perceive rituals through inherently biased narrative accounts of the events. Festival books are like Buc's problematic early medieval sources in that they 'purport to reveal the truth' and 'claimed a monopoly of legitimate interpretation' ${ }^{44}$ However, unlike the early Middle Ages, the range and volume of primary materials available to historians of late medieval and early modern Europe means that we have access to an abundance of non-literary texts (such as financial accounts) that can yield significant insights into the operation of an entry ceremony. Pre-modern France is not one of Buc's 'datapoor eras' where we can only use limited primary materials to provide 'a circumscribed realm of appropriate questions and possible results' about ritual and ceremonial practices. The abundant materials which exist in municipal archives across France make it possible to reconstruct many of the practices

\footnotetext{
42 Watanabe-O'Kelly, 'The Early Modern Festival Book', 8.

43 Keith Thomas, 'History and Anthropology', Past \& Present 24 (1963), 3-34; Natalie Z. Davis, 'The Possibilities of the Past', Journal of Interdisciplinary History 12 (1981), 267-75; Lynn Hunt, 'Introduction: History, Culture and Text', in Lynn Hunt, ed., The New Cultural History (Berkeley, 1989), 1-22.

44 Philippe Buc, The Dangers of Ritual: Between Early Medieval Texts and Social Scientific Theory (Princeton, 2001), 2.
} 
embedded within royal entries from the perspective of those people who actually planned the ceremonies. Accordingly, we do not need to follow Buc's call to banish social scientific models from the study of rituals. The careful use of well-chosen social-scientific theories has the potential to be of great value to historians of ritual and ceremonial behaviour, so long as they are sensitively used and applied to the sources of a particular historical period. The works of anthropologists such as Marcel Mauss and Marshall Sahlins on gift exchange are valuable precisely because their central assertions are borne out by the sources.

This book seeks to use extensive primary research to provide a sociopolitical context to the performance of these ceremonial practices. Records such as financial accounts and registers of municipal deliberations allow us to build-up a picture of the petitioning processes; they reveal the nature of the negotiations that took place between municipal governments and the Crown during an entry. ${ }^{45}$ These records explain what urban elites hoped to achieve by including elements such as the key presentation within an entry. Whereas festival books present the pageantry as the most important element of the event because it glorified the king, my examination of municipal records (especially the minutes of town council meetings) has revealed that urban governments spent the bulk of their time discussing the parts of the entry which related to the confirmation of existing liberties and the negotiation of new rights. Municipal records expose the formal and informal encounters that took place between the Crown and the urban elite during an entry, from the extramural confirmation of liberties to the purchasing of favours. Civic records were produced to provide an accurate record of what happened on the day of the entry and show how municipal councils had reached their decisions. It was important that municipal deliberations provided a rationale for the council's decisions about what practices to include in an entry because these records were used to prepare future entries. ${ }^{46}$

45 For the records of urban government, see: Caroline Fargeix, Les élites lyonnaises $d u$ $X V^{e}$ siècle au miroir de leur langue. Pratiques et représentations culturelles des conseillers de Lyon, d'après les registres de délibérations consulaires (Paris, 2007), 69-118; Jordi Morelló and Pere Verdés, 'Les dépenses municipales: essai de typologie', in Denis Menjot and Manuel Sáchez Martínez, eds., La fiscalité des villes au Moyen Âge (Occident méditerranéen) (Toulouse, 1996), 5-40; Graeme Small, 'Municipal Registers of Deliberations in the Fourteenth and Fifteenth Centuries: Cross-Channel Observations', in Jean-Philippe Genet and François-Joseph Ruggiu, eds., Les idées passent-elles la Manche? Savoir, Représentations, Pratiques (France-Angleterre, $X^{e}-X X^{e}$ siècle) (Paris, 2007), 37-66.

46 Typically, the first step town councils took when designing an entry was to look through their past deliberations to see how past dignitaries had been welcomed. See, for example: 
Unlike festival books, urban administrative records were not published. These documents were designed to act as the municipal council's exclusive record of the event and they were not intended for public consumption. Whereas festival books do not record the disagreements, jockeying for position and competition for places that lay behind the production of the ceremonies, these moments of disorder are laid bare in municipal deliberations. ${ }^{47}$ For example, the decades-long dispute about the procureur's position in the extramural procession in Parisian royal entries (which is extensively detailed in the municipal deliberations) is not mentioned in the festival book accounts of these entries, which were produced to emphasise the creation of social cohesion at an entry. Rather than providing an idealised account of how the event transpired, municipal records frequently provide examples of how entries went wrong or failed to achieve their intended outcome. From these documents, it is clear than many ceremonial entries did not encourage social cohesion. A comparison of urban administrative records with literary sources reveals that many of the practices town councils devised for their entries were not recorded in either chronicles or festival books. As deliberations were made with the expectation that only members of the municipal council would read them, they provide reliable accounts of the practices embedded within an entry. These records were not seen by anyone outside the inner council and they lay bare intentions, disputes and discussions surrounding the production of entries. For Philippe Buc, problems and inconsistencies with chronicles led him to state that 'one should give up the attempt to reconstruct the events [rituals]', in favour of looking at authorial intent in recording them. ${ }^{48}$ Yet the information contained in the plurality of documents held in municipal archives - especially non-narrative sources - allows us to reconstruct many of the practices that occurred during a ceremonial entry. ${ }^{49}$ By being careful to place the primary sources in their social and political context, we can move beyond the view that entries functioned as a means for the monarchy

Bonnardot, Registres Paris, 1499-1536, 211; Tuetey, Registres Paris, 1527-1539, 78; Le Verdier, Entrée de Louis XII à Rouen, xxii; Philippe Deschamps, 'Les entrées royales à Rouen', Connaître Rouen 3 (1976), 6. For ease of consultation Châlons-en-Champagne's town council placed their record of the 1445 entry of Charles vir and the dauphin at the beginning of a municipal register (which began fourteen years earlier) because it was designed to be the template for future entries: P. Pélicier, Ville de Châlons-sur-Marne. Inventaire sommaire des archives communales antérieures à 1790 (Chalons-sur-Marne, 1903), 36 .

49 Buc, Dangers of Ritual, 256. 
to achieve the ordering of society around the ruler and instead gain a more nuanced appreciation of these ceremonies.

\section{Geography and Chronology}

This book discusses entries into almost sixty towns and cities across the kingdom, from Calais in the northeast to Narbonne in far south, and from Bordeaux in the west to Lyon in the east. It also examines the production of ceremonial entries in the territories which were incorporated - or reincorporated - into of the kingdom of France by the Valois monarchs (such as Burgundy, Gascony and Provence), as well the role entries played in the expansion of French rule into Italy and the Holy Roman Empire from the later fifteenth century. In contrast to this wide geographical approach, most studies of French ceremonial entries are restricted to a single city, such as Michael Wintroub's work on Rouen or Pascal Lardellier's focus on Lyon. Foremost amongst the studies of a single city is Lawrence Bryant's examination of the Parisian royal entry. Indeed, the form of the Parisian entry is often seen as the model for other French towns and cities. For example, Richard Jackson writes that the entries staged at Reims were directly informed by knowledge of what was happening at Paris, though he fails to provide any examples of this transference of ideas. ${ }^{50}$ While postcoronation entries into the capital had a broader political significance, I have found little evidence of provincial urban administrations deliberately adopting the Parisian model as a template for their entries. Rather, municipal councils were more concerned to find out how their neighbours had welcomed the king and his representatives. As civic administrations were in direct competition for liberties with other towns in their region they hoped to trump their rivals by putting on a better show for the king - and thus be granted new rights at the expense of their neighbours.

It is necessary to take a wide geographical approach because the bulk of our knowledge about French ceremonial entries is based on the experiences of the major cities of the kingdom. As well as looking at the leading cities of the realm such as Lyon, Paris and Rouen, it is also important to examine the entries staged by less-powerful urban communities. By 1550, Paris (then the largest European city west of Istanbul) had a population of 250,000, while Lyon, Rouen and Toulouse had populations of between 50,000 to 75,000. Yet entries were not just a product of the great cities. At the other end of the urban spectrum, towns such as Pont-Audemer (pop. 2-3,00o) and Uzès (pop. 2,500)

50 Jackson, French Coronation Ceremony, 175 . 
also staged entry ceremonies. ${ }^{51}$ Small towns lacked the financial resources to put on an entry that rivalled the magnificence of those produced at Lyon and Rouen; nonetheless, these events filled the same basic function as the entries staged in the kingdom's leading cities. Although the frequency of entries varied from town to town, and depended on a range of circumstances (including geography, political conditions, the size and importance of an urban settlement, as well as seasonal factors, the personal wishes of the monarch, and numerous other reasons), most urban settlements could expect to receive a visit by the king at least once during his reign - and frequently more often. Furthermore, they could also expect visits from the monarch's representatives, including his immediate relatives and the provincial governors.

A ceremonial entry was a major event for a small town, especially those situated in remote parts of the kingdom, such as Auvergne or Languedoc. While large cities such as Paris or Lyon (as well as medium-ranking cities located close to centres of royal power such as Tours) could expect numerous visits from kings, smaller towns in more distant parts of the kingdom could not. This book follows the peregrinations of the Valois monarchy. Unlike the English court which was becoming settled around the south-east of England by the early sixteenth century, the Valois monarchs maintained their itinerancy right through to the reign of Henry III. As the court rarely covered more than twenty miles per day (and often less than ten), it halted both in large cities and small towns, thus providing the governments of all sizes of urban communities with an opportunity to gain contact with the king. While this book highlights some local variations in how kings were welcomed in different parts of France, it also shows that there were core similarities across the kingdom, particularly with regard to the ways in which urban elites sought the confirmation of their existing liberties and negotiated with the Crown for new ones. In short, entries had a similar function across France because regardless of a town's size and geographical location its rights had to be legitimised by the ruler.

On the rare occasions when studies of French entries look more broadly across the kingdom, they tend to have a restricted chronological focus. ${ }^{52}$ One of the main disadvantages with this approach is that we get little sense of how the entry ceremony evolved over time. Consequently, some historians have overstated the novelty or importance of developments in their own

51 Philip Benedict, 'Cities and Social Change', in Philip Benedict, ed., Cities and Social Change in Early Modern France (New York, 1992), 9; Bernard Michelin, 'Pont-Audemer, une petite ville de Normandie à la Renaissance (1477-1551)', 3 vols (Ph.D thesis, Université de Paris IV, 2005), i. 2.

See, for example: Boutier, Dewerpe and Nordman, Tour de France royal. 
period of study. In her examination of Henry IV's entries in the 159os, Annette Finley-Croswhite remarks that 'Henry's entries served to reunite the monarchy with estranged towns and heralded a reconciliation between the king and his urban subjects' and thus 'form[ed] an interesting chapter in the evolution of Renaissance rituals because they contained a unique aspect not present in the entries of other kings. ${ }^{.53}$ Yet such reconciliations were already apparent from the mid-fourteenth century and they also formed a key part of the reestablishment of Charles VII's rule in the 1430s and 1440s. The adoption of a broad chronological approach allows us to track the development of ceremonial practices over time rather than viewing a particular monarch's entries in isolation.

While the availability of festival books has led historians to overwhelmingly focus on Renaissance entries, this book considers the entire period of Valois rule. It was under the Valois monarchs that the French royal entry grew from being an unostentatious ceremony during the reigns of Philip VI and John II to reach its apogee under Henry II and Charles IX, when entries into the kingdom's principal cities lasted for several hours and provided a lavish audiovisual feast for the senses. However, while there was a change in the aesthetics and splendour of the welcome, the essential function of the entry remained the same for urban elites during the two-and-a-half centuries of Valois rule. Namely, these ceremonies provided municipal governments with a moment of face-to-face contact with the king and his representatives. It is also fitting that this book should end with the last Valois monarch, Henry III. After reaching its height under Henry II and Charles IX, the royal entry ceremony went into a sharp decline under Henry III, who fixed the Valois court around the Île-de-France and preferred closed court entertainments (such as ballets) to public entries; indeed, Nicholas Le Roux has found that 'under Henri III, urban entries virtually disappeared' ${ }^{54}$ By the reign of Henry III, the Crown permitted

53 Finley-Croswhite, Henry IV and the Towns, 48.

54 Nicholas Le Roux, 'The Politics of Festivals at the Court of the Last Valois', in Mulryne and Goldring, Court Festivals, 103. See also: Mark Greengrass, 'Henri III, Festival Culture and the Rhetoric of Royalty', in Mulryne, Watanabe-O'Kelly and Shewring, Europa Triumphans, i. 109-10; Nicholas Le Roux, 'Henri III and the Rites of Monarchy', in Mulryne, WatanabeO'Kelly and Shewring, Europa Triumphans, i. 116-21. Henry III avoided making ceremonial entries even before he ascended to the French throne. When he came to Nantes in July 1573, for example, Albert de Gondy, count of Retz, was sent to inform the town council that Henry did not wish to make an entry and would instead lodge in a house in the suburbs: AM Nantes AA 34. While entries declined under Henry III, they reappeared under the first Bourbon monarch. Once neglected, the entries of the Bourbon monarchs, especially those of Henry IV, have formed the focus for recent works on French royal entries. 
the cities of the kingdom to spare the expense of preparing a magnificent entry by offering a payment in lieu of the ceremony. According to the journal of Pierre de l'Estoile, Rouen paid 20,00o livres to the Crown instead of staging a welcome for Henry III in June 1578. L'Estoile remarks that 'the king took [the money] to give to his mignons. This was found very strange. ${ }^{55}$ Offering the king a payment instead of preparing an entry may have saved the town money but it denied them the opportunity to win new liberties and was thus to the overall disadvantage of the town (and its economy). Henry III's dislike of public entries contributed to the creation of a gulf between the last Valois king and his urban subjects, and it is perhaps no surprise these conditions led to widespread urban participation in leagues against the French monarchy. ${ }^{56}$

\section{Overview}

The key questions that drive this book are those that consider how urban elites used ceremonial entries to negotiate with the Crown for liberties. Chapter one analyses the strategies municipal councils took to ensure that the king confirmed their rights during the extramural greeting. This chapter begins with an examination of the greeting speech, which urban governments used to ask the king to confirm their existing liberties. As this was a pivotal moment in the entry ceremony, it was the object of extensive preparations by urban administrations. The manner in which kings responded to municipal greetings, particularly through the display of gesture and emotion, was crucial to the granting of liberties. Furthermore, urban leaders used holy objects (such as relics) both

See, for example: Michael P. Breen, 'Addressing La Ville des Dieux: Entry Ceremonies and Urban Audiences', Journal of Social History 38 (2004), 341-64; Finley-Croswhite, Henry IV and the Towns, 47-62; Yann Lignereux, Lyon de le roi: de la "bonne ville" à l'absolutisme municipale (1594-1654) (Seyssel, 2003), 57-65; Ann W. Ramsey, 'The Ritual Meaning of Henry IV's 1594 Parisian Entry', Russell and Visentin, French Ceremonial Entries, 189-206; Marie-France Wagner and Daniel Vaillancourt, eds., Le Roi dans la ville. Anthologie des entrées royales dans les villes françaises de province (1615-1660) (Paris, 2001); Marie-France Wagner, ed., Les entrées royales et solonnelles du règne d'Henri IV dans les villes françaises, 2 vols (Paris, 2010); Marie-France Wagner, 'Le spectacle de l'ordre exemplaire ou la cérémonies de l'entrée dans la ville', in Marie-France Wagner and Claire Le Brun-Gouanvic, eds., Les arts du spectacle dans la ville (1404-1721) (Paris, 2001), 113-35.

55 Pierre de l'Estoile, Mémoires-journaux, 1574-1611, 12 vols (Paris, 1875-96), i. 257.

56 Elie Barnavi, Le Parti de Dieu. Étude sociale et politique des chefs de la Ligue parisienne, 1585-1594 (Brussels-Louvain, 1980); Robert Descimon, Qui étaient les seize? Mythes et réalités de la Ligue parisienne, 1585-1595 (Paris, 1983). 
to encourage the king to act in a deferential manner during the confirmation of municipal rights and to raise the status of this act to that of a sacred oath. The chapter then moves on to assesses the significance of objects such as keys and banners for the winning of urban liberties, demonstrating that these items were more than simple tokens of a town's submission to its lord. This chapter also suggests that an evolution in the form of the extramural greeting changed the nature of the confirmation of urban liberties during the mid-sixteenth century. In particular, the growth of a physical distance between the king and civic delegations at the extramural greeting lent a greater significance to the direct contact which urban leaders gained with the king at the post-entry greeting.

Where chapter one analyses the ratification of old liberties, chapter two examines how urban administrations used an entry to win new rights. It begins by reassessing debates about the perceived openness of the Valois court. Whereas the customary view is that the French court was easily accessible before the later sixteenth century, this chapter shows that such claims have been overstated. While Valois monarchs claimed to be open to receive petitions from all their subjects, urban governments found it difficult to gain access to the king under normal circumstances. In contrast, a royal entry provided municipal elites with guaranteed access to the monarch and his ministers. This access became especially important during the sixteenth century, when the French king became more remote in the extramural greeting. After illustrating how urban administrations gained contact with the king, this chapter moves on to explore the role that gift-giving played in the winning of new rights and liberties. It uncovers the strategies that towns deployed at this stage of the ceremony and considers how effective they were in the winning of new liberties, before going on to provide a typology of the requests towns brought to the monarch at a royal entry. This chapter also reveals the ways in which urban petitions related to both national and local pressures and shows how the nature of these requests changed over time.

Chapter three focuses on the crucial role that the French king's household played in the granting of liberties. It shows how entries allowed urban governments to develop networks of clientage with influential brokers at court. Whereas studies of clientage in pre-modern France typically focus on the nobility, this chapter contributes to wider debates on the operation of clientage in France by putting the spotlight on urban elites. It shows how royal favourites and key brokers helped ensure that the king and his ministers received urban petitions favourably. Entries were a particularly important means for smaller towns (which could not afford to keep delegations at court) to gain access to those in power. Finally, it examines the entries of royal women, whose intimate relationship with the king made them powerful brokers. This chapter 
demonstrates that towns devised entries specifically to obtain favours from these women, which they could draw on in the future to win new liberties.

Building on the discussion of royal women, the final chapter focuses on the entries of the provincial governors, who, like the queen, represented the monarch. While governors were amongst the most powerful royal officials in France, their entries are rarely studied. Yet, as a consequence of their increasing powers, governors' entries were an important means for towns to obtain liberties and recruit powerful brokers at court. As governors represented the person of the king in the provinces, there were heated discussions across France about how they should be received. By the middle of the sixteenthcentury, governors' entries had become so magnificent that they were almost indistinguishable from those of the king. This chapter demonstrates that honours traditionally reserved for the king were accorded to governors specifically to reward their services for urban governments. Governors' entries were also crucial events for townspeople because they had the power to confirm urban liberties and issue grants in the monarch's name. As well as examining governors' entries, this chapter also considers how urban governments staged ceremonial entries to win the favour of deputy governors, baillis and sénéchaux, whose receptions have been omitted from previous studies of French entries. The chapter concludes with an analysis of the receptions civic leaders gave to governors' wives to recruit their services as brokers.

All of the following chapters are concerned with the ways in which urban elites interacted with the king and his representatives. My principal focus is on how municipal governments used entries to try and win influence with the decision-making core which lay at the heart of the French government. Accordingly, this book is based upon extensive research in the records of urban governments. Furthermore, in contrast to the numerous studies that examine the pageantry of these events, this book approaches ceremonial entries from a social-political perspective. It focuses on the urban elites who devised this ceremony in order to interact with the king and his representatives and win concessions from them. Despite appearances of immutability, the entry was not a static ceremony; it evolved over time and in response to a number of stimuli, such as the needs of urban elites, the transformation in town-Crown relations from the mid-fifteenth century, changing political conditions in France and the concomitant development of the character of the Valois monarchy. It is the thesis of this book that ceremonial entries were important events for municipal elites because they allowed them to win the advantageous rights and liberties that secured their dominant position at the pinnacle of urban society. All the endeavours detailed in the following chapters were driven towards this end. 